\title{
THE ASCUS APEX IN LICHENIZED FUNGI II. THE RHIZOCARPON-TYPE*
}

\author{
ROSMARIE HONEGGER $†$
}

\begin{abstract}
Ascus structure of eight yellow, two white and two brown Rhizocarpon species has been investigated by light microscopy. Ultrastructure and function in $R$. atroflavescens subsp. pulverulentum and $R$. montagnei were studied in TEM.

The Rhizocarpon-type ascus clearly differs from all other ascus types observed in the Lecanorales. It is bitunicate, opening with a slight 'Jack-in-the-box'-mechanism. Its structure and function are related to patellariacean ascus types, but unlike those the ascus wall cytochemistry shows a certain similarity with Lecanora- and Peltigera-type asci. Rhizocarpon-type asci are embedded in a strongly amyloid hymenial gelatine. The nonamyloid ascus wall is surrounded by the strongly amyloid outer layer. The slightly amyloid expansible inner layer (= endoascus) is apically thickened; it shows the banded and pleated 'accordion-structure ' characteristic of bitunicate asci. Prior to dehiscence, the ascus wall and its outer layer burst. Thereafter the pleatings of the expansible inner layer are stretched, forming the rather short beak which reaches the hymenial surface. During expansion gliding occurs between the expansible inner layer and an outer part of the endoascus, here described as the 'inner layer'. In a few sections of aldehyde- fixed material of $R$. atroflavescens a small laminated plug was observed in the apex of the endoascus.

Rhizocarpon-type asci are considered to be the most archaic in the Lecanorales. This supports a hypothesis that Rhizocarpon is a phylogenetically basal group, linking the evolved Lecanorineae, and possibly also the Peltigerineae and Teloschistineae with not yet recognized bitunicate ancestral forms similar to those occurring in the Patellariaceae.
\end{abstract}

\section{Introduction}

Living in symbiosis with algae is a nutritional specialization of various unrelated higher fungi, many of which belong to orders containing both lichenized and nonlichenized species (Henssen \& Jahns 1973; Barr 1976). The Lecanorales, however, are probably anciently lichenized and form the main group of lichenized fungi with more than 10000 species, and seem to have very few non-lichenized members; their taxonomic position as well as their phylogenetic origin are a matter of debate.

On the basis of ontogenetic and physiologic criteria, Nannfeldt (1932) and Dughi (1957) supposed that the Lecanorales evolved from archaic ascomycetes. On the basis of comparative studies of ascus structure and ascocarp ontogeny of lichenized as well as non-lichenized fungi, Chadefaud and his coworkers (Chadefaud, 1973; Chadefaud et al. 1963, 1969; Letrouit-Galinou 1973) take the lecanoralean fungi to be the most archaic group amongst extant ascomycetes. These authors support the hypothesis that recent bitunicate as well as unitunicate ascomycetes evolved from lecanoralean 'type archaeascé' asci (which is considered as bitunicate). From comparative studies of ascus fine structure and function in different lecanoralean

\footnotetext{
* I in Lichenologist 10: 47-67(1978).
}

† Institut für Pflanzenbiologie, Abt. Cytologie der Universität Zürich, Zollikerstrasse 107, CH-8008 Zürich, Switzerland. 
the apical region (weakly visible in Fig. 1a); this phenomenon was also observed in Lecanora-type asci (Honegger 1978a, b). Both ascus wall and the lamellate outer part of the expansible inner layer disappear. The remaining equally thin layer (Figs $1 \mathrm{k}, 6 \mathrm{~b}$ ) around the ascospores seems no longer to be elastic (it was the expansible inner layer prior to the onset of disintegration). At the beginning of a period of higher humidity, many of the disintegrating asci are extruded out of the hymenium, probably due to the pressure of the swelling hymenial gelatine, and then are often seen lying both on the hymenium surface and on neighbouring areolae. It is conceivable that at least some of these 'ascus packets', as well as ascospores ejected in the normal way, are dispersed by rain or melting snow water running over the thalli. Some of the mature ascospores which are trapped in the hymenium germinate (Fig. 6b) but later these all die. Lateral outgrowths of neighbouring paraphysoids penetrate the remaining thin ascus wall as well as the decomposing ascospores, probably partly resorbing them. Clumps of amorphous ascospore walls can be observed in the basal parts of the hymenium as well as on its surface.

\section{Electron Microscopy}

Surprisingly few investigations on the fine structure of bitunicate asci have been carried out (Reynolds 1971; Bellemère 1971; Griffiths, in Beckett et al. 1974; Honegger 1978b). Reynolds (1971) described the particularly interesting banded and pleated structure of the endoascus in Limacinula theae Sydow \& Butler (Dothiorales); this accordion-like structure of the endoascus seems to be characteristic of bitunicate asci.

Asci from Rhizocarpon atroflavescens subsp. pulverulentum and $R$. montagnei were investigated by TEM. Following fixation with aldehyde and osmium the ' accordion-like structure' of the expansible inner layer is clearly visible (Figs 2a, $4 a-b)$. During dehiscence the pleatings of the apically thickened endoascus are stretched (Figs 5a-b). Following fixation with potassium permanganate, however, the ' accordion-like' structure is only weakly visible, but with this fixation method a few electron-dense granular inclusions scattered over the whole expansible inner layer are seen (Figs $2 \mathrm{~b}, 3 \mathrm{~b}$ ). These inclusions resemble those of the apical dome of Lecanora-type asci, where electron-dense granules are very frequent and conspicuous and were presumed to constitute the amyloid character of the apical dome (Honegger 1978a, $b$ ). This may be true for the endoascus of Rhizocarpon as well as of that of Peltigera (Honegger, 1978b); both are bitunicate types with a slightly amyloid endoascus.

FIG. 1. Ascus structure of different Rhizocarpon species in LM. a-d, stained with lactophenolcotton blue; $\mathrm{e}-\mathrm{g}$, stained with Lugol's solution. a, $R$. atroflavescens subsp. pulverulentum, $\times 800$. b-c, $R$. concentricum, $\times 800$. d, $R$. montagnei, $\times 800$. e-f, $R$. riparium subsp. lindsayanum, $\times 800 ; \mathrm{f}$, Squash preparation, on squashing the amyloid outer layer bursts, the nonamyloid ascus wall and the slightly amyloid expansible inner layer with a ringlike zone in the thickened apex are visible. For comparison: $\mathrm{g}$, Physcia stellaris, a Lecanora-type ascus with its characteristic strongly amyloid apical dome, the nonamyloid apical cushion and the ocular chamber, $\times 1200 \mathrm{~h}-\mathrm{k}$, Semithin sections about $0.5 \mathrm{ltm}$ from plastic embedded material of $R$. alpicola stained with toluidine-and methyleneblue at high $\mathrm{pH}$. $h, \mathrm{~A}$ young (still growing) ascus and one during deposition of the expansible inner layer, shortly after ascospore delimitation, $\times 1200$. i, Ascus near maturity, $\times 1200 . \mathrm{k}$, Decomposed ascus with degenerating ascospores; after dissolution of the outer layer, ascus wall and parts of the expansible inner layer, an equally thin wall layer surrounds the degenerated ascospores, $\times 1200$ 

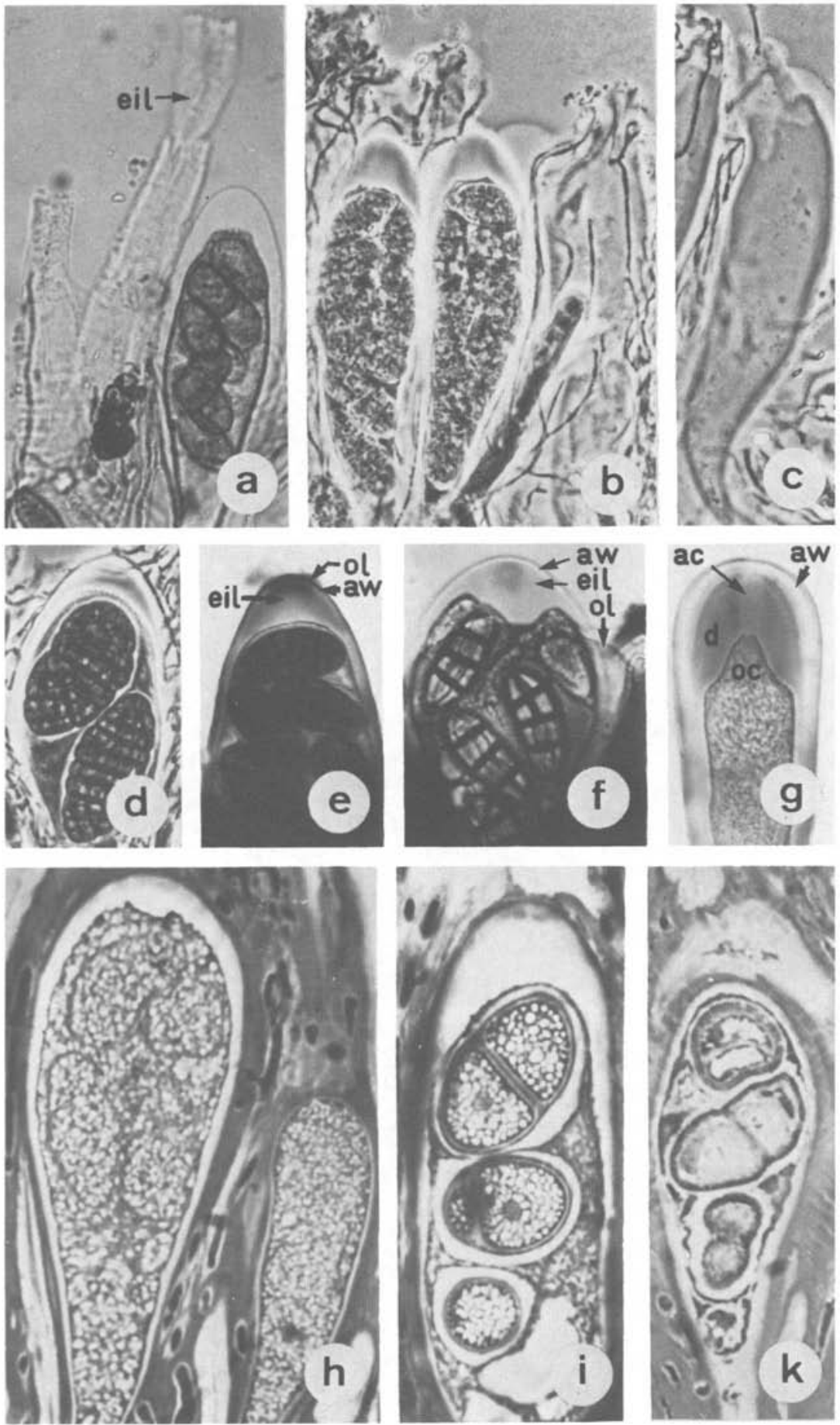


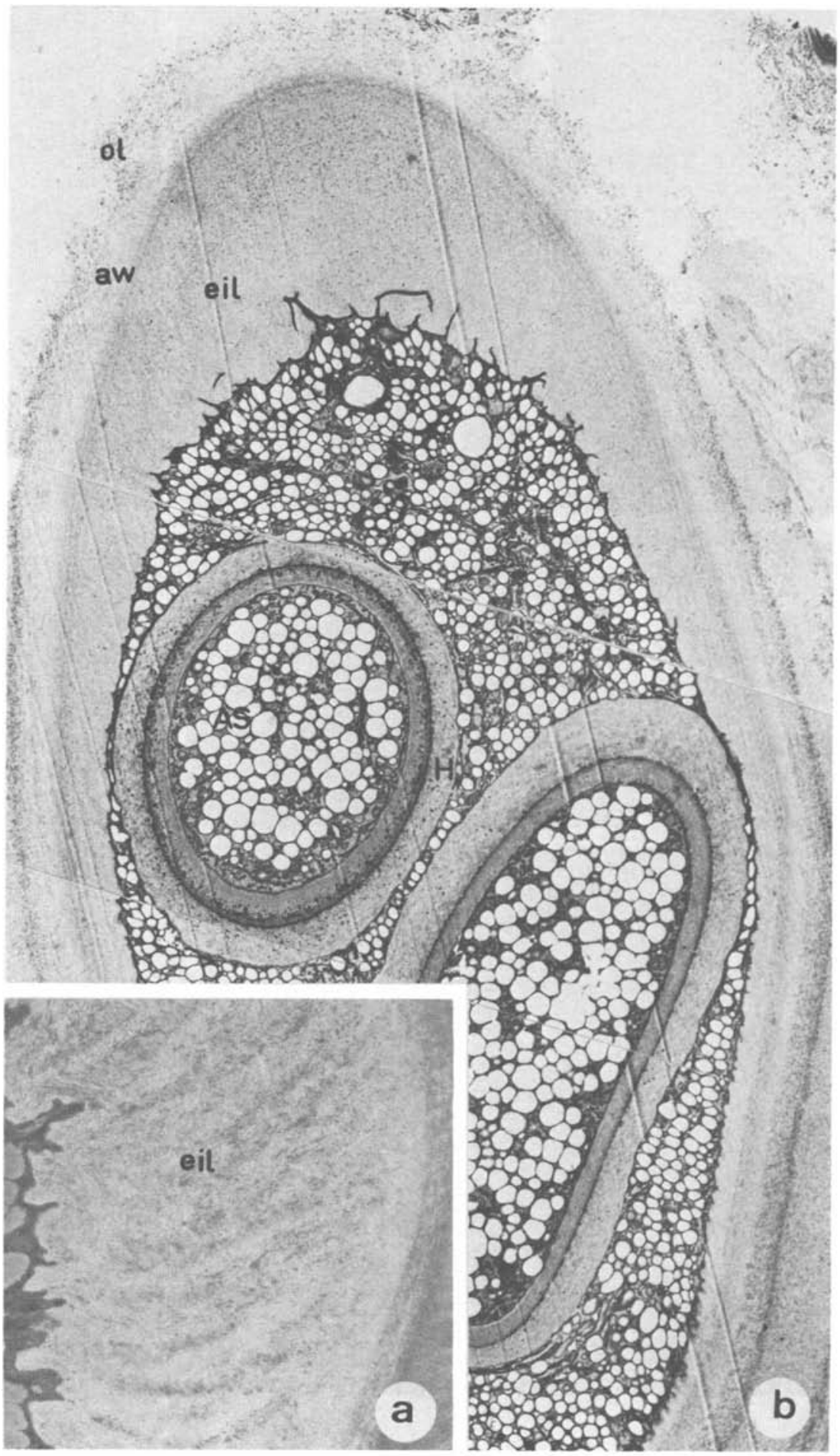


A very small laminated plug observed in the central apical part of the endoascus in $R$. atroflavescens (Fig. 3a) might correspond to the nonamyloid centre of the ringlike amyloid zone observed in LM (Fig. 1f); this plug might play a role during dehiscence. Comparable structures have been observed in pollen germ pores (Rowley 1975).

During dehiscence gliding occurs not directly between the ascus wall and the expansible inner layer, but rather between an outer part of the endoascus, here referred to as the 'inner layer' and the inner part of the endoascus, the 'expansible inner layer' (Figs 5a-c). Gliding occurs over a rather short distance. The beak formed by the stretched expansible inner layer is, in comparison with other bitunicate fungi, rather short but nevertheless reaches the hymenial surface.

The degradation process observed in LM was also studied in TEM. The thin and even wall layer around the spores which remains after the lytic processes shows no particular structure (Fig. 6a). The penetration of decomposed asci and degenerating ascospores by outgrowths from the paraphysoids are seen in Fig. $7 \mathrm{~b}$.

\section{Ascospores}

Rhizocarpon ascospores are cytologically interesting. The halo around the strongly pigmented exospore has a similar structure to the expansible inner layer of the ascus; it is deposited at the same time as the innermost part of the endoascus. A conspicuous difference between Rhizocarpon and members of the Lecanorineae yet studied is seen: in Rhizocarpon meiosis and ascospore delimitation occur during endoascus formation, whereas in the Lecanorineae investigated (Honegger 1978a) meiosis and ascospore formation take place after deposition of the apical apparatus. The function of the halo is not understood, but it is conceivable that it acts as an adhesive fixing the ejected spore to the substrate.

In $R$. atroflavescens spores a germ pore-like structure was observed (Fig. 3c). Concentric bodies, formerly supposed not to occur in ascospores, nor in asci (Griffiths 1972), were frequently observed in ascospores (Figs 3d, 6a); they were also seen in ascus cytoplasm (e.g. the ascus in Fig. 2b, but in a lower section).

\section{Discussion}

According to the present and former studies (Honegger, 1979) the Rhizocarpon species investigated belong to the bitunicate discomycetes (sensu Butler 1939, 1940). Henssen \& Jahns (1973) introduced the term ' Zwischentyp ' for ascomycetes with bitunicate asci and ascohymenial development, emphasizing the position of this group between the two main groups of Ascomycetes (i.e. Ascohymeniales/ Ascoloculares sensu Nannfeldt 1932; Unitunicatae/Bitunicatae sensu Luttrell 1951). Although the term 'discomycete' is rarely strictly defined, it is usually applied to apothecia-bearing Pezizales, Helotiales, and Lecanorales. The ascocarps of bitunicate discomycetes so far investigated, however, seem to be discothecia in

FIG. 2. Ascus structure of Rhizocarpon atroflavescens subsp. pulverulentum, in TEM. a, Lateral part of the apical thickening of the expansible inner layer showing the 'accordion-structure' characteristic of bitunicates, $\times 9000$. b, Part of an ascus showing the different wall layers, $\times 3800$. Fixation: $a$, glutaraldehyde and osmium tetroxide; b, potassium permanganate. AS, ascospore; aw, ascus wall; eil, expansible inner layer; $\mathrm{H}$, halo of ascospore; ol, outer layer of ascus wall. 


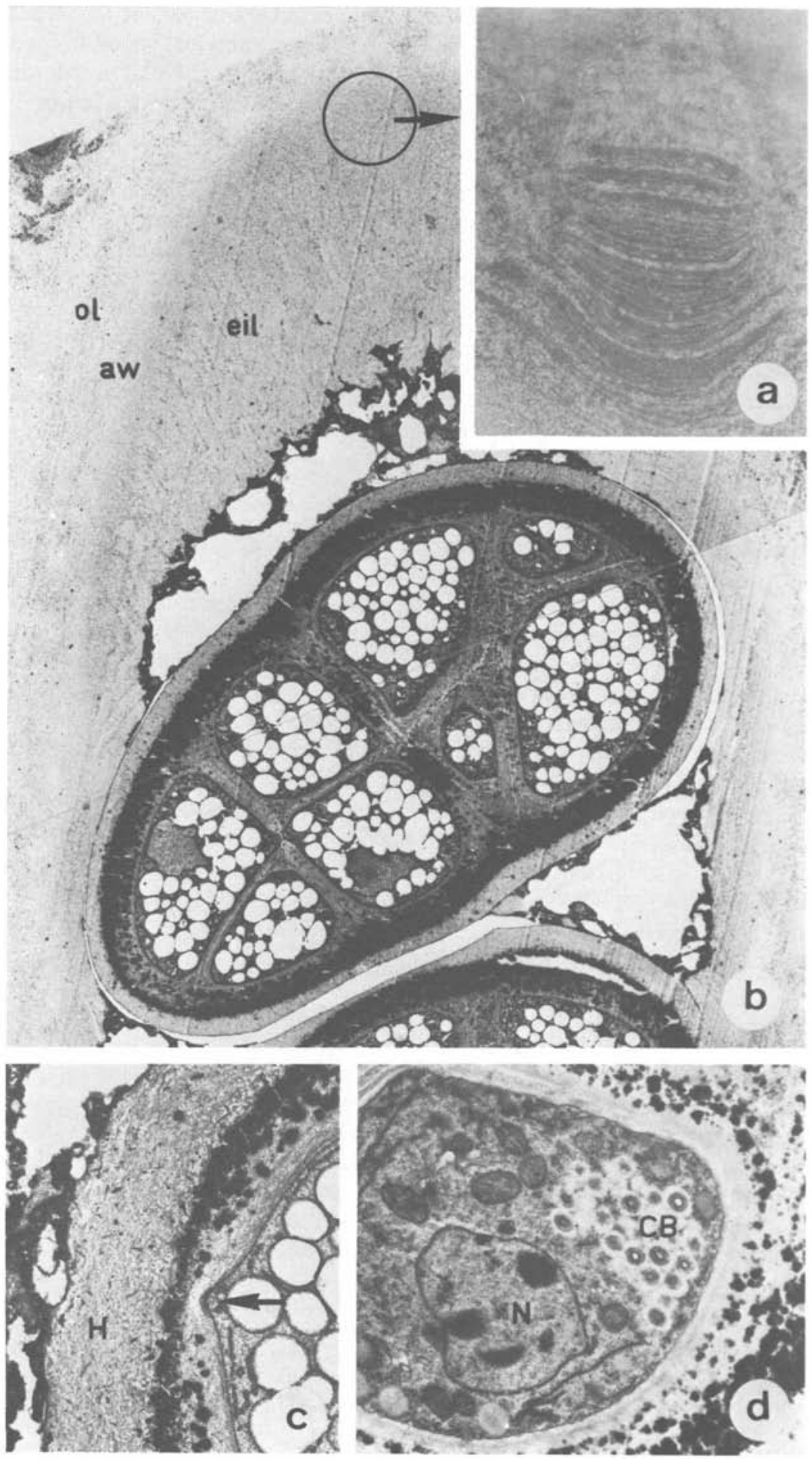


the sense of Pirozynski \& Reid (1966). In consequence the term 'bitunicate discomycetes ' might better be replaced by ' ascohymenial bitunicates'.

As mentioned by various authors, the ascohymenial bitunicates represent an archaic group amongst extant ascomycetes (Santesson 1949; Parguey-Leduc 1966, 1967; Bellemère 1971). The lichenized fungi of the genus Rhizocarpon, with their primitive ascocarp development (Honegger, 1979) and the thick-walled bitunicate asci are therefore of particular interest. The fact that some Rhizocarpon species (e.g. members of the $R$. geographicum-complex) are world-wide in their distribution, although not forming vegetative propagules, could be interpreted as indicating a considerable age for this group.

With respect to their structure and function, Rhizocarpon asci, as thick-walled bitunicates with a slight ' Jack-in-the-box' mechanism, resemble ascus types in the Patellariaceae (Butler 1939, 1940; Pirozynski \& Reid 1966; Muthappa 1967, 1970; Bellemère 1971; Hafellner \& Poelt 1976a; Hafellner 1979). The chemical composition of ascus wall layers, as far as can be concluded from the rather primitive cytochemical methods so far employed, show some similarity between Rhizocarpon and lecanoralean asci; both are also embedded in a strongly amyloid hymenial gelatine. The Patellariaceae, and Karschia Körber in particular, were interpreted by Nannfeldt (1932) as the basal group from which the Lecanorales could have evolved. Hafellner \& Poelt (1976a) and Hafellner (1979) have, however, conclusively demonstrated that, first, the genus Karschia was extremely heterogenous, including taxa with bitunicate as well as Lecanora-type asci, and secondly, that the differences between the bitunicate Karschia species and the Lecanorales are so conspicuous that a natural developmental line between them has to be excluded. It should be re-emphasized that Buellia de Not. is not synonymous with Karschia, as has been suggested by some authors (Müller \& von Arx 1962; von Arx \& Müller 1975); Buellia species have unitunicate-inoperculate Lecanora-type asci as demonstrated by LM (Letrouit-Galinou 1961, 1973; Hafellner 1979) and TEM techniques (Honegger 1978a, b) and therefore clearly belong to the Physciaceae.

Relationships between Rhizocarpon and other bitunicates, e.g. the Patellariaceae, are not yet understood; further studies on ascus fine structure and ascocarp ontogeny in this family are needed. As pointed out by Hafellner (1979), comparative studies on the ascus ultrastructure in the patellariacean genus Dactylospora, containing saprophytic as well as lichenicolous species, might be particularly interesting. The non-amyloid Dactylospora asci develop in a nonamyloid hymenial gelatine. At maturity they have a distinctive strongly amyloid gelatinous cap at their apex; this cap does not correspond to the strongly amyloid dome of Lecanora-type asci.

Some relationships between Rhizocarpon and other Lecanorales are, on the basis

FIG. 3. Fine structure of the mature ascus and ascospores in Rhizocarpon atroflavescens subsp. pulverulentum. $\mathrm{a}-\mathrm{b}$, Apical part of the ascus; in the uppermost central part of the endoascus a small plug is seen, its lamellate structure is visible in aldehyde-fixed material; this plug might correspond to the centre of the slightly amyloid ring-like zone observed in LM (Fig. 1f); a, $\times 18000, b, \times 3800$. c, Germpore-like structure (arrow) in an ascospore, $\times 20000$. d, Concentric bodies in an ascospore, $\times 9000$. Fixation: b, d, glutaraldehyde and osmium tetroxide; a, c, potassium permanganate. aw, ascus wall; CB, concentric bodies; eil, expansible inner layer (= endoascus); $\mathrm{H}$, halo of ascospore; $\mathrm{N}$, nucleus; ol, outer layer of ascus wall. 


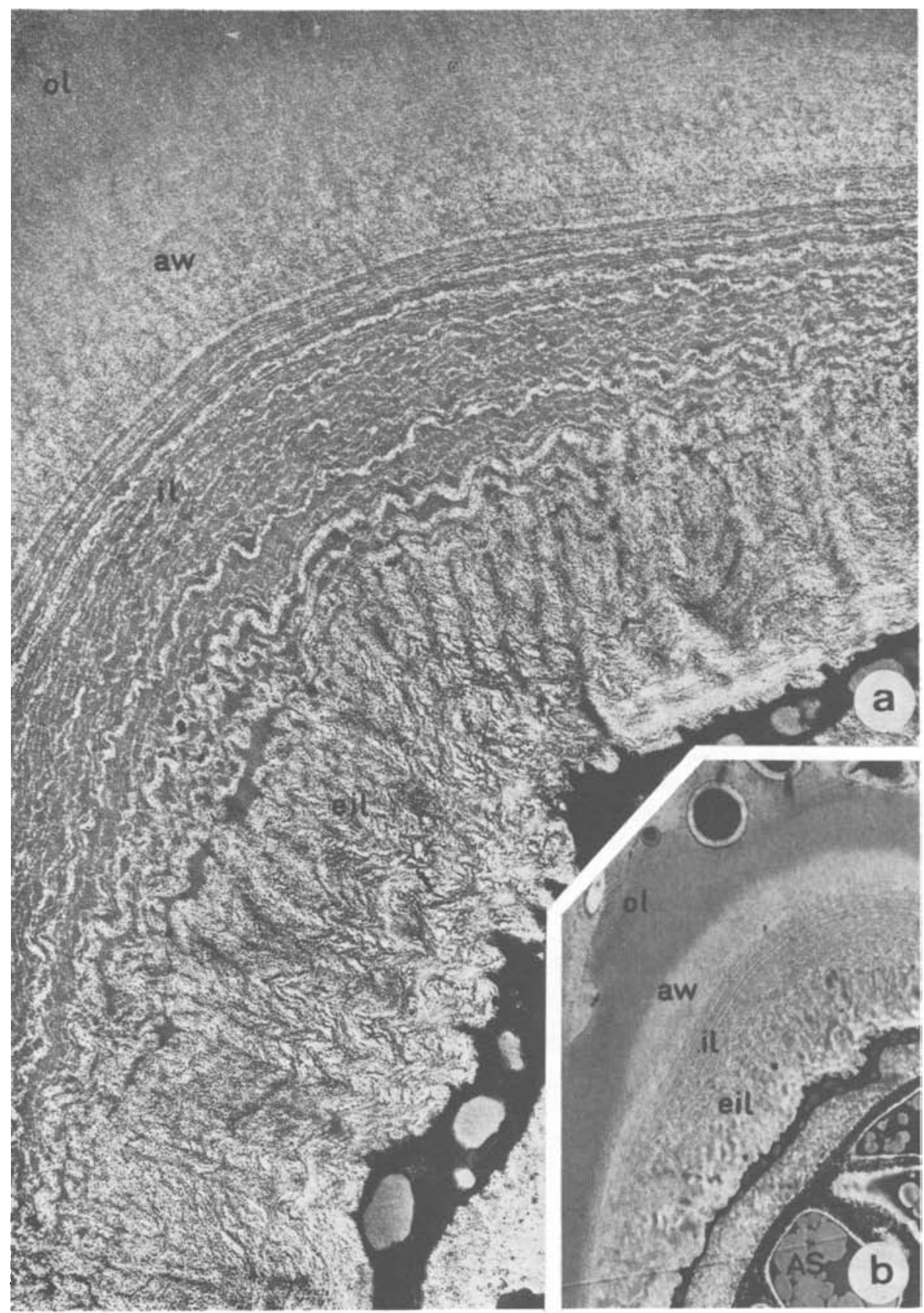

FIG. 4. Fine structure of ascus apex in Rhizocarpon momagnei. a, b, Part of ascus apex showing different wall layers. During dehiscence gliding occurs between the expansible inner layer and the inner layer. a, $\times 18000, b, \times 2700$. Fixation: $a$, b, glutaraldehyde and osmium tetroxide. AS, ascospore; aw, ascus wall; eil, expansible inner layer; il, inner layer; ol, outer layer of ascus wall. 

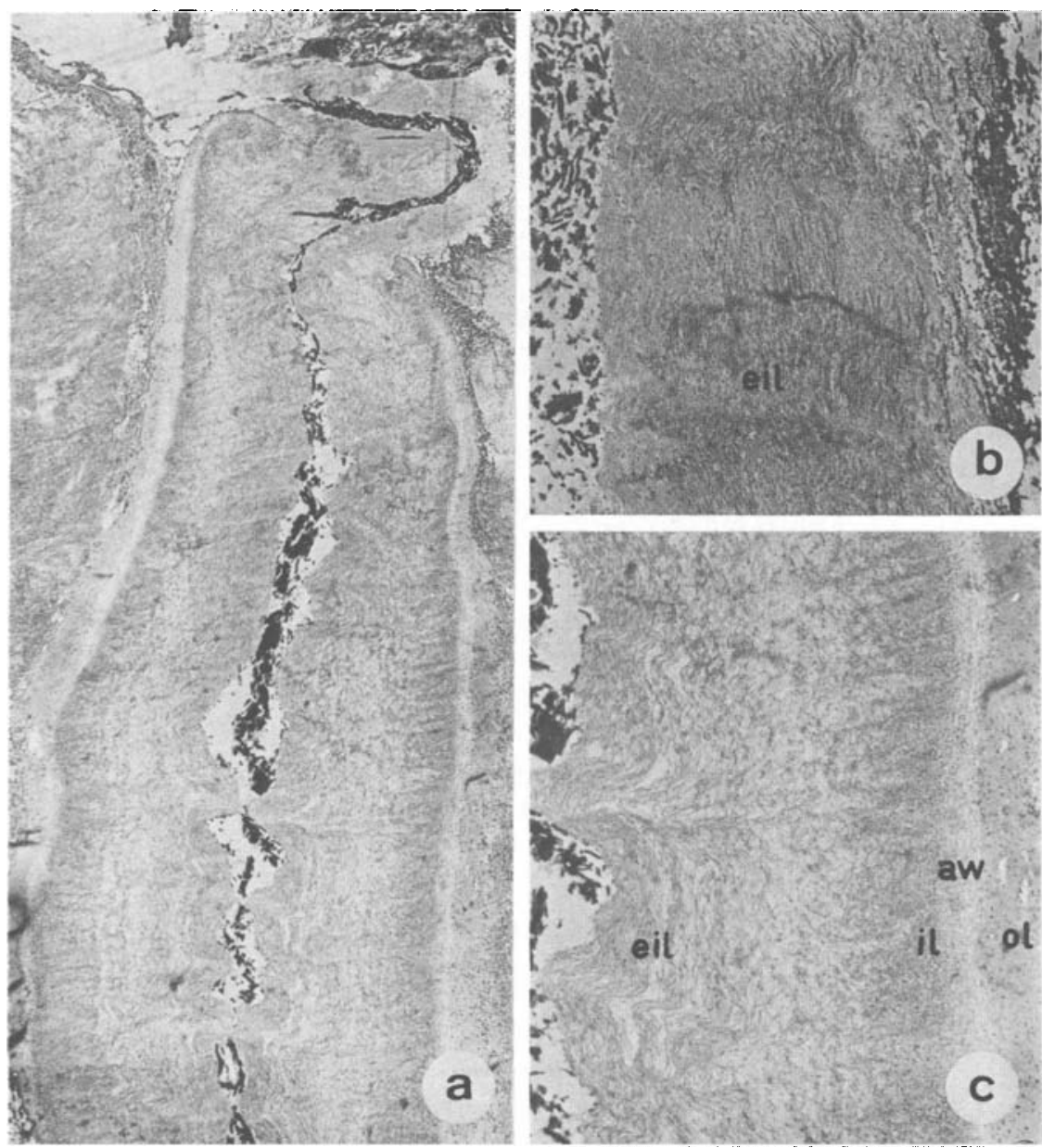

FIG. 5. Fine structure of ascus wall layers after ascospore discharge in Rhizocarpon atroflavescens subsp. pulverulentum. a, The rather short beak is curved and therefore tangentially sectioned, $\times 6300$. $b$, Part of the stretched zone of the expansible inner layer, $\times 14000 . c$, Part of the unstretched, but no longer compressed, expansible inner layer showing the pleatings of bitunicates, $\times 14000$. Fixation: a-c, glutaraldehyde and osmium tetroxide. aw, ascus wall; eil, expansible inner layer; il, inner layer; ol, outer layer.

of ascus fine structure, recognizable. The Rhizocarpon-type ascus can be interpreted as a basal form, from which, by a reduction of the expansible inner layer to an apical dome and by an intensification of its amyloid character, the unitunicateinoperculate Lecanora-type could have evolved. There is some evidence that the Lecanora-type derives from a thickwalled bitunicate. In the early stages of ascus development at the beginning of the apical dome formation, it is found that a thin layer of the conspicuous dome material is deposited not only at the apex but also inside the whole primary ascus wall (Honegger 1978b: pl. 1c). This material becomes integrated into the ascus wall in the lateral and basal parts of the ascus and is no longer recognizable in mature asci; this might, however, be interpreted as a 

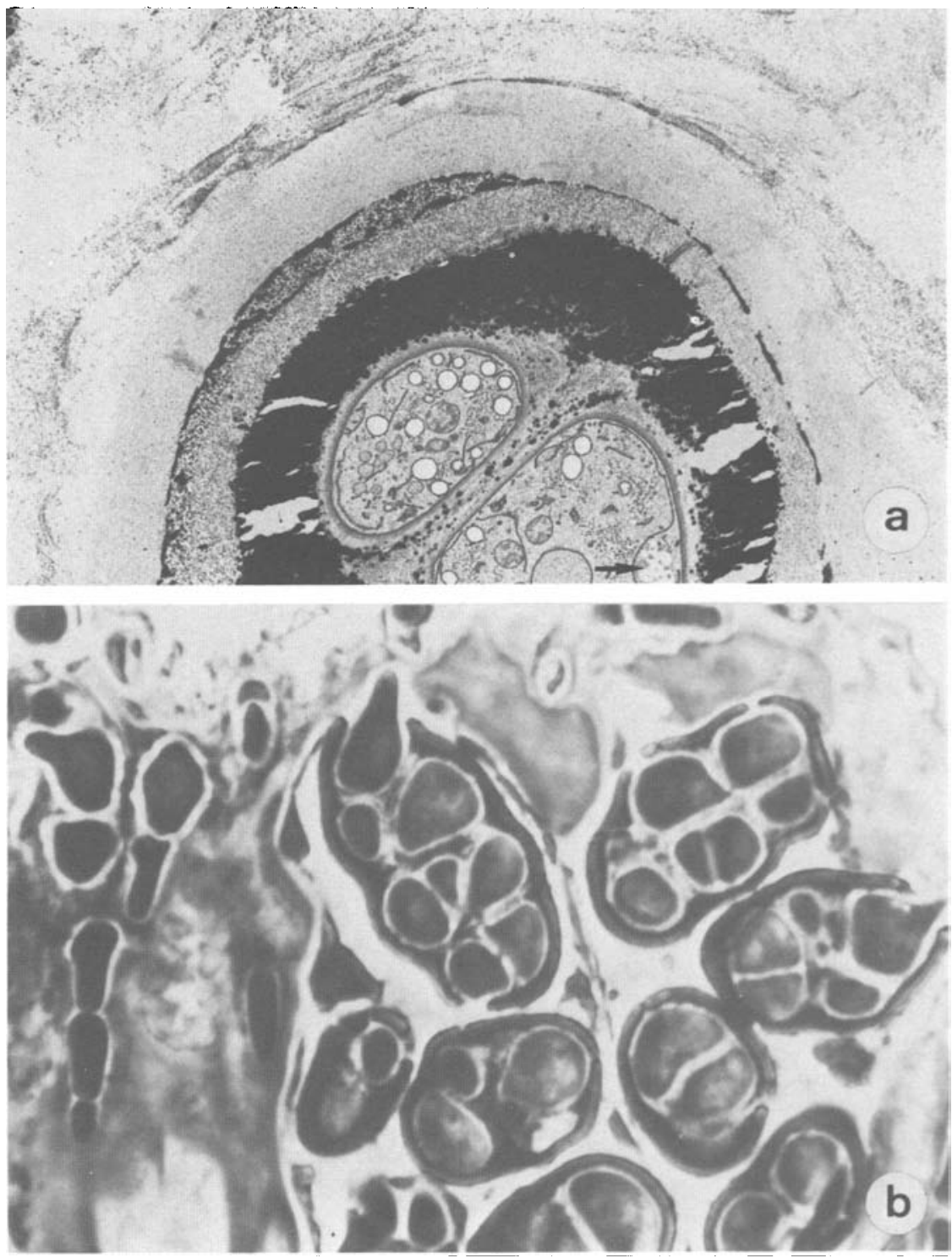

FIG. 6. Ascus decomposition in Rhizocarpon atroflavescens subsp. pulverulentum. a, Part of the apical region of a decomposed ascus with the equally thin innermost part of the endoascus remaining. The cytoplasm of the ascospores seems to be intact; concentric bodies are seen (arrow), $\times 6300$. Fixation: potassium permanganate. b, Light micrograph of decomposed asci with germinating ascospores, $\times 2200$. Semithin section from plastic embedded material.

remnant of former endoascus formation. Rhizocarpon can thus be taken as a link between the still unknown bitunicate ancestors and the rather evolved Lecanorineae (inclusive of the Physciaceae) sensu Henssen \& Jahns (1973). Moreover, it is imaginable that the bitunicate Peltigera-type with its slightly amyloid expansible 

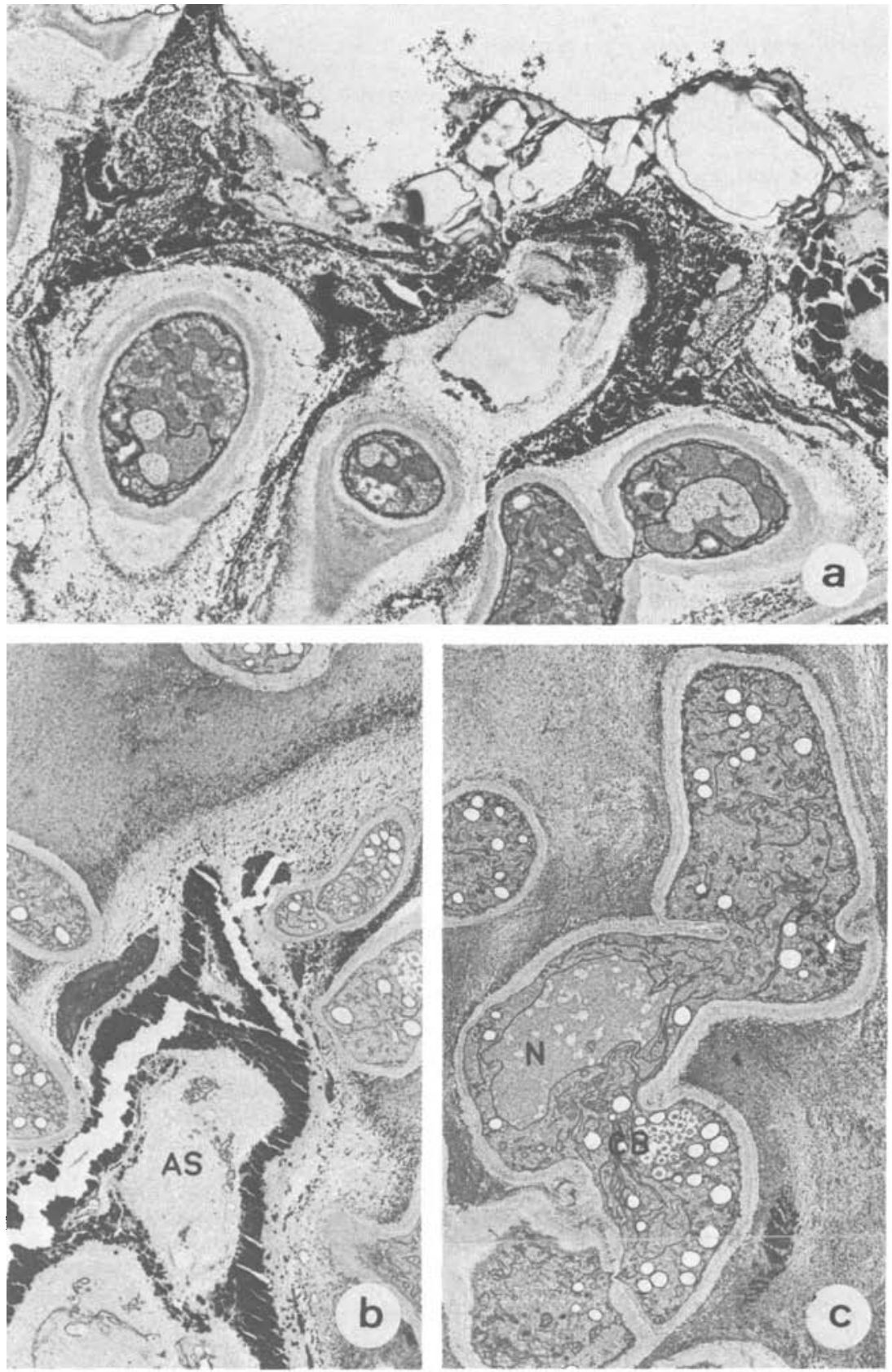

FIG. 7. The hymenium of Rhizocarpon atroflavescens subsp. pulverulentum. a, The 'epihymenium' with the terminal cells of paraphysoids embedded in an amorphous mass of remnants of lysed, degenerate ascospores and the lysed material which formerly convered the ascocarp primordium, $\times 6300 . \mathrm{b}$, Decomposed ascus and degenerate ascospores at the base of the hymenium, penetrated by outgrowths of neighbouring paraphysoids, $\times 6300$. c, Ascogenous hyphae with concentric bodies, $\times 6300$. Fixation: $a-c$, potassium permanganate. 


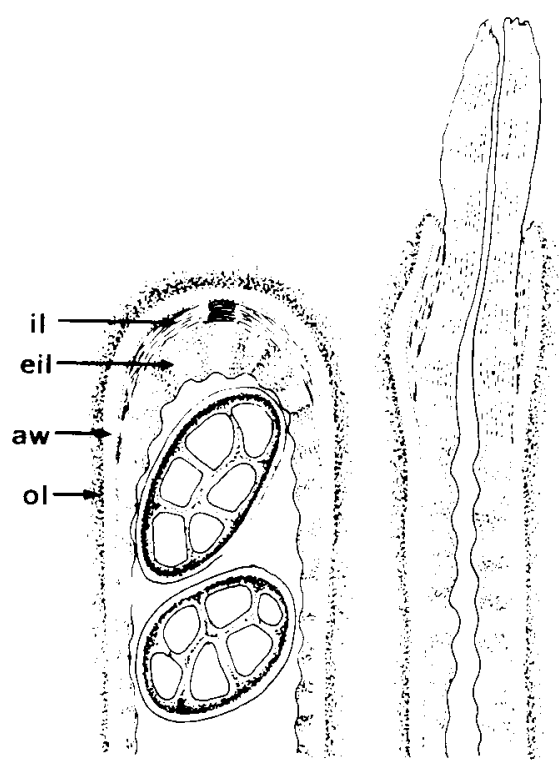

FIG. 8. Diagram of ascus structure and function in Rhizocarpon atroflavescens subsp. pulverulentum according to LM And TEM observations. aw, ascus wall; eil, expansible inner layer; il, inner layer; ol, outer layer.

inner layer and the eversible amyloid ring (Honeggar 1978b) as well as the functionally unitunicate Teloschistes-type derive from Rhizocarpon-type or similar forms. This interpretation corresponds to a certain degree to the phylogenetic concepts of Chadefaud (1973) and Letrouit-Galinou (1973); these authors are looking to a thick-walled bitunicate 'type pré-archaeascé' as an ancestor of the Lecanora-type ('type eu-archaeascé ') and of all other ascus types occurring in Euascomycetes.

For further elucidation of the problems discussed above, and the taxonomic position of the genus Rhizocarpon in particular, comparative studies of ascus fine structure and function, ascus wall composition and ascocarp ontogeny in both lichenized and non-lichenized fungi are needed. It is possible that in a future taxonomic revision of the Lecanorales, Rhizocarpon will be placed in separate suborder, comparable to the Pertusariineae, Peltigerineae and Teloschistineae (sensu Henssen \& Jahns 1973).

Valuable information on the phylogeny and taxonomy, as well as symbiology might be derived from the study of the biology of symbiotic and host-parasite interactions in lichens and lichenicolous fungi. With regard to these questions investigations of Rhizocarpon would probably be particularly interesting. This genus is an example of one 'cutting across biological boundaries' (Hawksworth 1978), including autotrophic, lichenicolous, as well as scarcely lichenized species (like R. schedomyces, a parasite of other lichens; Hafellner \& Poelt 1976b).

I am greatly indebted to Prof. Dr A. Henssen for stimulating discussions, encouragement, the loan of herbarium specimens and facilities to study her extensive collections of permanent LM preparations of various lichenized fungi. Thanks are also due to Dr D. L. Hawksworth for reading and correcting the manuscript. 


\section{REFERENCES}

von Arx, J. A. \& Müller, E. (1975) A re-evaluation of the bitunicate Ascomycetes with keys to families and genera. Stud. mycol., Baarn 9: 1-159.

Barr, M. E. (1976) Perspectives in the Ascomycotina. Mem. N. Y. bot. Gdn 28: 1-8.

Beckett, A., Heath, I. B. \& McLaughin, D. J. (1974) An Atlas of Fungal Ultrastructure. London: Longman.

Bellemère, A. (1971) Les asques et les apothecies des Discomycètes bituniqués. Annls Sci. nat. (Bot.), sér. 12, 12: 429-464.

Butler, E. T. (1939) Ascus dehiscence in Lecanidion atratum and its significance. Mycologia 31: $612-623$.

Butler, E. T. (1940) Studies in the Patellariaceae. Mycologia 32: 791-823.

Chadefaud, M. (1973) Les asques et la systematique des Ascomycètes. Bull. trimest. Soc. mycol. Fr. 99: $127-170$.

Chadefaud, M., Letrouit-Galinou, M.-A. \& Favre, M. C. (1963) Sur l'évolution des asques et du type archaeascé chez les discomycètes de l'ordre des Lecanorales. C. r. hebd. Séanc. Acad. Sci., Paris, sér. D, 257: 4003-4005.

Chadefaud, M., Letrouit-Galinou, M.-A. \& Janex-Favre, M. C. (1969) Sur l'origine phylogénétique et l'évolution des Ascomycètes des lichens. Bull. Soc. bot. Fr., Mém. 1968 (Coll. lich.): 79-111.

Dughi, R. (1957) Membrane ascale et reviviscence chez les champignons licheniques discocarpes inoperculés. Annls Fac. Sci. Marseille 26: 3-20.

Glück, H. (1899) Entwurf einer vergleichenden Morphologie der Flechten-Spermogonien Heidelberg: Carl Winters Univ.- Buchhandlung.

Griffiths, H. B. (1972) The concentric bodies of lichenized fungi. Arch. Mikrobiol. 87: 285-302.

Hafellner, J. (1979) Karschia, Revision einer Sammelgattung an der Grenze von lichenisierten und nichtlichenisierten Ascomyceten. Beih. Nova Hedwigia 62: 1-316.

Hafellner, J. \& Poelt, J. (1976a) Die Gattung Karschia-Bindeglied zwischen bitunicaten und lecanoralen Flechtenpilzen? Plant Syst. Evol. 126: 243-254.

Hafellner, J. \& Poelt, J. (1976b) Rhizocarpon schedomyces spec. nov., eine fast delichenisierte parasitische Flechte, und seine Verwandten. Herzogia 4: 5-14.

Hawksworth, D. L. (1978) The taxonomy of lichen-forming fungi: reflections on some fundamental problems. In Essays in Plant Taxonomy (H. E. Street, ed): 211-243. London, New York, San Francisco: Academic Press.

Henssen, A. \& Jahns, H. M. (1973) ["1974"] Lichenes. Eine Einführung in die Flechtenkunde. Stuttgart: Thieme.

Honegger, R. 1978a) Licht- und elektronenoptische Untersuchungen an Flechten-Asci vom Lecanoratyp. Dissertation, Universität Basel.

Honegger, R. (1978b) The ascus apex in lichenized fungi I. The Lecanora-, Peltigera- and Teloschistestypes. Lichenologist 10: 47-67.

Honegger, R. (1979) Ascocarpontogenie, Ascusstruktur und -funktion bei Vertretern der Gattung Rhizocarpon. Ber. dtsch. Bot. Ges. 91: 579-594.

Lamb, I. M. (1968) Antarctic lichens. II. The genera Buellia and Rinodina. Scient. Rep. Br. Antarct. Surv. 61: $1-129$.

Letrouit-Galinou, M.-A. (1961) Étude du developpement des apothecies chez Buellia canescens. Bull. Soc. bot. France 108: 281-290.

Letrouit-Galinou, M.-A. (1968) The apothecia of the discolichens. Bryologist 71: 297-327.

Letrouit-Galinou, M.-A. (1973) Les asques des lichens et le type archaeascé. Bryologist 76: 30-47.

Luttrell, E. S. (1951) Taxonomy of the Pyrenomycetes. Univ. Missouri Stud. 24(3): 1-120.

Müller, E. \& von Arx, J. A. (1962) Die Gattungen der didymosporen Pyrenomycetem. Beitr. Kryplogflora Schweiz 11(2): 1-922.

Muthappa, B. N. (1967) Tryblidiella rufula on diverse substrata and its taxonomic position. Nova Hedwigia 14: 395-401.

Muthappa, B. N. (1970) Morphology of Tryblidiella clavispora. Mycologia 62: 98-106.

Nannfeldt, J. A. (1932) Studien über die Morphologie und Systematik der nichtlichenisierten, inoperculaten Discomyceten. Nova Acta R. Soc. Scient. upsal., ser. 4, 8(2): 1-368.

Parguey-Leduc, A. (1966) Recherche sur l'ontogénie et l'anatomie comparée des ascocarpes des Pyrenomycètes ascoloculaires. Annls Sci. nat. (Bot.), sér. 12, 7: 505-609; 8: 1-130.

Parguey-Leduc, A. (1967) Recherches préliminaires sur l'ontogénie et l'anatomie comparée des ascocarpes des Pyrenomycètes ascohymeniaux. I. Notions générales. Revue mycol. 32: 57-68. 
Pirozynski, K. A. \& Reid, J. (1966) Studies on the Patellariaceae. 1. Eutryblidiella sabinae. Can. f. Bot. 44: $655-661$.

Reynolds, D. R. (1971) Wall structures of a bitunicate ascus. Planta 98: 244-257.

Rowley, J. R. (1975) Germinal apertural formation in pollen. Taxon 24: 17-25.

Santesson, R. (1949) Dolichocarpus and Xanthopeltis, two new lichen genera from Chile. Svensk bot. Tidskr. 43: 547-565.

Accepted for publication 20 December 1979 